\title{
Using a Blended Learning Strategy to enhance Official Language Prep School Students'English Creative Writing Skills
}

\section{BY}

Khalid Sayed Shalaby Ali

Senior Teacher of English 


\section{Using a Blended Learning Strategy to enhance Official Language Prep School Students'English Creative Writing Skills}

Khalid Sayed Shalaby Ali

ملخص البحث: : n

تهدف الدراسة الى التحقق من فعالية برنامج مدمج لتعزيز مهار ات الكتابة الإبداعية باللغة الإنجليزية لطلاب المرحلة الإعدادية بالمدارس الرسمية للغات ـ بناء على مر اجعة النقد الادبي

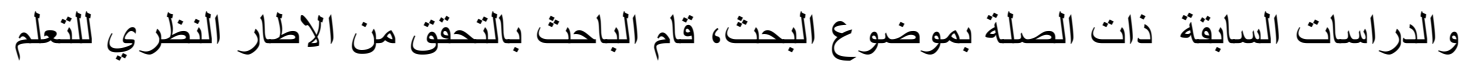
المدمج و مهارات الكتابة الإبداعية ـ ولقد اثتملت ادوات البحث على قائمة تضمنت مهارات الكتابة الابداعية ، الامتحانين الكتابيين القبلي والبعدي ، ونموذج تحليلي للكتابة الابداعية ، إستبيان وتقرير حول المردود نحو البرنامج ـ ولقد صمم ايضا برنامج للتعلم المدمج يقوم على مهار ات الكتابة الإبداعية ـ و عين لهذه الدر اسة فصل مكون من 24 طالب وطالبة بالصف الثالث الاعدادي في مدرسة النيل الرسمية للغات ببني سويف ـ ولقد اتخذ هؤلاء الطلاب كمجوعة تجريبية واحدة لتلقي تدريب برنامج التعلم الدممج ـ ولقد تم تحليل نتائج الامتحانين القبلي و البعدي باستخدام إختبارT وتم حصر حجم التاثير. اضافة الى ذلك، تم استخدام الإستبيان لجمع المعلومات الكيفية حول مردود الطلاب نحو البرنامج ـ و تم عمل تقرير حول مردود البرنامج من قبل معلم اخر كان شاهدا على تطبيق البرنامج لتحقيق الموضوعية والحيادية في تقييم البرنامج ـ ولقد اظهرت المعلومات الكمية والكيفية حول البرنامج ان هناك فرق دال بين نتائج الإمتحانين القبلي والبعدي لصالح الاخير ـ في الوقت نفسه، وجد هنالك اختلافا بين الطلاب المشاركين في الدر اسة كافر اد ـ وفي النهاية ، يمكننا ان نستنتج ان استر اتيجية التعلم المدمج كان لها فعالية مؤثرة في تعزيز ليس فقط مهارات الكتابة الإبداعية وبخاصة في كتابة المذكرة ولكن ايضا في تقوية المهار ات الاجتماعية و التفكيرية بين الطلاب ـ إضافة الى ان للتعلم المدمج دورا في انعاش المناخ التعليمي وزيادة الدافعية و التعاون بين الدتعلمين.

$$
\text { والاستعار ات ـ الصورة: التعلم المدمج ـ المذكرة ـ المتنكرون ـ الوصف الحيوي ـ التشبيهات }
$$




\begin{abstract}
:
The aim of this study was to investigate the effectiveness of a blended leaning program on enhancing official language prep school students' English creative writing skills. Based on reviewing the literature review and the previous related studies, the researcher investigated the theoretical framework of blended learning and creative writing skills. The research instruments included a list of creative writing skills, a pre-post writing test, an analytical creative writing skills rubric, a satisfaction questionnaire and a reflection report. Also, a blended learning program based on creative writing skills was designed. A whole class of twentyfour $3^{\text {rd }}$. prep graders from Nile official school for languages in Bani Suef was assigned to be one experimental group which received training through the blended learning program. The pre and posttests in the creative writing skills were statistically analyzed using T-Test and the effect size was calculated. Also, the satisfaction questionnaire was administered to collect the qualitative data about the program impact and the students' feedback. The reflection report was administered with an external teacher who acted as an observer or a second eye for objective evaluation. Both the quantitative and qualitative data about the program showed that there were statistically significant differences between the pre and post test results in favor of the later. Simultaneously, there were significant differences among all the students' results as individuals. Finally, it was concluded that blended learning paradigm had a magnificent effectiveness in enhancing not only the students' creative writing skills particularly in memoir writing, but also in substantiating the social and cognitive skills among students. It is worthy to mention that blended learning could refresh the atmosphere of learning and increase the students' motivation and cooperation.
\end{abstract}

Keywords: Blended Learning - Creative Writing - Memoir - Memoirists - Vivid description - Similes and metaphors - Anecdotes - Figures of speech - emotional appeal 


\section{Introduction:}

Creative writing is a special kind of writing which is characterized as so involving that it requires more concentration. Creative writing is referred to as the writing which takes people's attention. It is also considered as a source of pleasure to its readers or any writing that is original and self-expressive. A news article, for example, cannot be considered creative writing, because its main goal is to present facts and not to express the feelings of the writer. Creative writing includes poetry, plays, movies and television scripts, fictions (novels, novellas, and short stories), songs, speeches, personal essays and memoirs.

Memoir writing can be creative because it is written in the first person. Memoir is a longer piece of creative non-fiction that delves deep into a writer's personal experience. When teaching memoir, teachers ask students to construct narrative versions of their lives, remember events and people from their past, or invent additional details and dialogues. Teachers ask students also to consider the "So what?" of their remembered stories. Creative memoir writing involves characters, plot development, vivid setting, viewpoints, dialogue, anecdotes, similes and figures of speech. Memoir writing can be taught via blended learning which may help students to converse, question and comment on each other's work.

\section{Statement of the problem:}

The $3^{\text {rd }}$ prep graders at Nile Official School for Languages in Beni Suef Governorate, Egypt, lack the fundamental principles of creative writing which help them to create pieces of writing which are thoughtful and critical. This problem was documented through English exam- 
marking experiences and consultation with English supervisors and teachers.

\section{Research Questions:}

Main Question: "To what extent can a blended learning program enhance the official language $3^{\text {rd }}$ prep school graders' English creative writing skills?"

The following sub-questions emanated from the above major one:

1. How competent are the $3^{\text {rd }}$ prep students in English creative writing?

2. What difficulties do students encounter during the writing process?

3. How can blended learning help students to overcome these difficulties?

4. What are the students' reflections after the program completion?

\section{Literature Review:}

In a brief differentiation between writing and speaking discourses; Richards, (2003) explains that written language employs different syntax, vocabulary, clauses, verb phrases, tenses and devices. Langan (2007: 1012), illustrates that "In writing, any idea that you advance must be supported with specific reasons or details". Keys,(2000) explains that teaching writing encourages planning, evaluating, and revising. Thus, teachers should be aware of the writing conventions (Kapka, and Oberman 2001), and help students analyze ideas (Tang, 2006).

Creative writing definitely is not an ordinary kind of writing but a sophisticated and special one. Passion is essential for creative writing, as it can push up the temperature of the written voice. However, Creative writing has such challenges as the students' lack of self-confidence, shortage of knowledge and non-proficiency. Also, they may be unable to 
contribute to online discussions, entries in e- Portfolios, content for websites and emails (Ramet, (2011).

Memoir is a remarkable piece of creative writing. Gilbert, (2003) defines memoir as the most popular and expressive literary form of our time. Memoir is a distinct literary genre and a form of autobiography. It is the text that describes aspects of the author's life. Memoir reveals what happened to ordinary citizens of those worlds and the moral consequences. The hallmark of memoir is the ability of the writer to discover meaning in his/her life (Murdock, 2010). However, memoir has such challenges as the lack of real data mined from the face of life. Memoirists may think that writing memoirs inevitably means exposing embarrassing or shameful truths to peers. Memoirists may refuse to provide a chronology of their lives, but only now capturing their own previously undefined selves (Coen, 2009). Writers always begin by writing down what they consider the first memories of their own life such as birthdays. Writers try to remember details, clothes, ornaments, sensations, etc. Memoir writing can best be taught via blended learning.

Blended learning is the convergence of face-to-face synchronous settings with the asynchronous communication technology-based settings in which human operates independently (Graham, 2004: 3-5). Blended learning offers opportunities for personalization, self-directedness, variety and learning communities (Ausburn, 2004). "When the strengths of each approach are integrated in an appropriate and creative manner, the possibility to become fully engaged is increased exponentially (McGee and Reis, 2012:9). Blended learning fosters students' interactivity \& allows using different resources (Huang and Wang, 2006). It encourages 
social sharing and learning (Stefanovich et al.2011). Blended learning facilitates the student acceptance and satisfaction (Harris, Connolly, and Feeney, 2009); increases active learning, peer-to-peer learning, learnercentered strategies, the collaboration of team projects and student engagement (Smelser, 2002). It also empowers student reflection and the storage of course content (Clouder, 2008:199). Blended learning courses reduce costs, time, provide tools (chat rooms) (Slotkin, Durie, \& Eisenberg, 2012). It provides students with collaboration (Vasileiou, 2009), and results in reflective interaction (McCown,2010)

However, students' access to online materials may decrease their need for physical attendance in the classroom and reduces personal engagement in learning (Stewart et al. 2011). Students may not have the same learning styles and they may be less interested in reading (Dziuban et al. 2005). Managing curriculum design and online discussions may be difficult (McCown, 2010). Also some students who are proficient in online technologies may become dissatisfied with less proficient instructors (Gradel and Edson 2010:193-196).) \& (Stewart et al. 2011). Other challenges are such as the teachers' and learners' attitudes; their access to technology and the cost of materials (Sharma and Barrett, 2007:12-13).

\section{Study Method :}

\section{Study Design}

After determining the study statement and reviewing the related literature, the researcher adopted the quasi-experimental design because it combines between validity and reliability from one hand, and the rich contextual information from the other hand. This approach aimed at examining the effectiveness of a blended learning program on enhancing the $3^{\text {rd }}$ prep 
graders' English creative writing skills particularly in memoir writing at Nile official school for languages in Bani Suef. A whole classroom of students was selected as an experimental group to receive training via this program. Pre and post-tests were administered before and after the intervention stages to measure the program effectiveness in promoting the students' creative writing skills. Also a satisfaction questionnaire was used to reflect the students' feedback regarding the blended program impact. At the end, a reflection report was submitted by an external teacher observer as a second eye to add more validity and reliability to the study findings.

\section{Sample of the study:}

Ebeedat et al. (2005: 132) define the sample as "A part of the study main population". The study sample was determined through the simple random method. The sample was selected randomly and consisted of (10) students away from the original or main study participants. Clear cut instructions on how to answer the questions were given. The aims were to correct any inconvenient items, to experiment the pretest validity and reliability before being used.

\section{Study Participants:}

The main participants of this study were the $3^{\text {rd }}$ prep graders at Nile official school for languages in Bani Suef, for the scholastic year 20162017. The participants of this study $(\mathrm{n}=24)$ included 12 males and 12 females. Their ages ranged from 14-15years and they all have the same schooling background. The study participants number seems to be small; however "the smaller the student population sample size, the more positive experiences there will be" (Slotin et al. (2013:171). 


\section{Study Treatment:}

\section{A. Before Study Treatment}

A brief description of the study was included in a letter for the participants.

Privacy and confidentiality were maintained.

The researcher recorded the differences between the male and female students' English creative writing skills prior to the program via the pretest.

\section{B. After Study \\ C. Treatment}

By the end of this study, the following nine hypotheses are predicted to take place:

1. "There is a statistically significant difference at 0.05 level between the students' pre \& posttest mean scores regarding the clarity and interest of the main idea and supporting details in favor of the posttest due to B. learning".

2. There is a statistically significant difference at 0.05 level between the students' pre \& posttest mean scores regarding the strong flow and excellent sequence of ideas due to blended learning".

3. "There is a statistically significant difference at 0.05 level between the students' pre \& posttest mean scores regarding the writer's care about his topic due to blended learning."

4. "There is a statistically significant difference at 0.05 level between the students' pre \& posttest mean scores regarding the use of accurate word choice and figurative language." 
5. "There is a statistically significant difference at 0.05 level between the students' pre \& posttest mean scores regarding the writer's use of organization and conventions in favor of the posttest."

6. "There is a statistically significant difference at 0.05 level between the Male \& Female students' mean score in the pre \& posttest regarding their creative writing skills due to such factors as gender and individual differences".

7. "The satisfaction questionnaire is expected to achieve validity, stability and reliability in distinguishing among individual views".

8. "The students' attitudes and feedback towards the effectiveness of blended learning program in enhancing their creative writing skills may witness very positive and motivating reflection".

9. "Observation is predicted to emphasize the blended program effectiveness on enhancing the students' creative writing kills".

Note: Testing hypotheses was through T-Test, Cornback Alpha, the Comparison terminal, the classroom observation and the report.

\section{Study Instruments:}

1. A list of creative writing skills and sub-skills.

2. Writing pre-post skill tests.

3. Analytical writing skill rubric.

4. Satisfaction questionnaire for the proposed program.

5. A reflection report made by an external teacher observer

\section{Creative Writing Skills List:}

A list of creative writing tasks was given to students during the program via the synchronous face to face setting and the asynchronous online one. 


\section{The Content of Creative Writing skills List :}

Hard \& soft memoir samples, videos, photos and picture books.

\section{Sources of the skills identified:}

Reviewing literature \& previous related studies, recording the students' writing interests, taking from training courses.

\section{Validity of the Creative Writing skills List}

The content material was submitted to jury members who are involved in the field of teaching English as a foreign language and linguistics to determine its suitability.

\section{The Creative Writing Skills Test \& Aims}

The test is the most suitable tool for collecting accurate data that help in making accurate decisions. The researcher used it to measure the participants' achievement before and after the experiment. Results were statistically analyzed via T-Test and the Cronbach's alpha \&spilt half by Spearman-Brown coefficient.

\section{Description:}

This pre-test was about "A sport that changed your life). The posttest was about "Someone that you knew and admired". (Appendices are available on request) The content consisted of the following:

- A cover page for students including instructions related to the test.

- Assessing creative writing was via a rubric adopted by the researcher.

- The total score of the test is 24

The test was constructed in the light of the following:

a. Bearing in mind the students interests and favorite topics.

b. The writing skills determined by the researcher and modified by the jury. 
c. Identifying the test objective as to measure the students' creative skills.

d. Identifying the writing skills that are necessary for students

e. Designing the test items evaluated by the jury for validity \& consistency.

f. Piloting the test to ensure the clarity of items after preliminary tryouts.

g. Modifying the test according to the jury members and put in final form.

\section{Test Validity:}

Tests were reviewed by experts in language teaching. A cover letter explaining the aim of the test and what experts should do was delivered to experts. The aim was to determine the relevance of each item to the skill it measure; as well as its suitability.

\section{Piloting the Test:}

The writing pretest was administered to a random pilot sample of (10) students who were not included in the program. Clear cut instructions on how to answer the questions were given. The aims were to establish the reliability of the test, check suitability to students, and determine the appropriate time. Analyzing the statistics value of the test reliability showed that the reliability coefficient of the test was appropriate, which means that the test was reliable and stable.

\section{Analytical Writing Skills' Rubric:}

Students writing skills were measured by using an analytic rubric, which was chosen and preferred as a holistic rubric that gives a detailed profile about students' performance. The rubric consists of five criteria and each criterion has four rating scales. The five criteria represent the main creative writing skills aimed to be assessed in the pre/posttests. These five 
skills included: the clarity of topic, flow and sequence of ideas, speaking voice, figurative language, and writing conventions. Each criterion had four rating levels. The highest level is out of four, while the lowest is out of one.

Rubric Validity: The rubric validity was checked by experts in teaching. Consultation resulted in a series of substantive changes in my assessment.

\section{Students' Satisfaction Questionnaire:}

A satisfaction questionnaire was used to determine to what extent students were satisfied with blended learning. It consisted of 10 items. It was a five point Likert-Scale ranging from strongly agree, agree, neutral, disagree, and strongly disagree.

\section{Satisfaction Questionnaire Validity:}

This questionnaire was reviewed by a group of experts in English language teaching from different foundations including university professors, supervisors and teachers. Their recommendations were taken into consideration.

\section{Observation Reflection Report:}

The researcher wanted to have a second eye that could observe the program context as a whole, to ensure how the program was going on, and to form an objective evaluation. The researcher provided the observer with some guiding questions. The observer was free to add any extra details about his observation. The guiding questions were about the teaching performance, students' participation, the program implementation, the challenges and the wishes that had to be carried out. 


\section{The Blended Learning Program}

Description of the Program

- An introduction to the program

- Bases of designing the proposed program.

- The program teaching strategies

- Aims and objectives of the program.

- Content and material of the program.

- The adopted blended learning Model

- Piloting the program.

- Teaching methods.

- Setting of the program.

- Duration.

- Assessment techniques.

\section{Introduction to the Program}

- An outline of the program overall and detailed objectives.

- How the program is going to be taught and assessed.

- What students should do inside and outside classrooms

\section{The Bases of the Program Design}

This program was designed in the light of two main dimensions:

- The process dimension or how the program was implemented.

- The product dimension that refers to the expected outcomes. As the focus was on creative writing, the product was skill oriented. 


\section{The Program Strategies}

\section{A. Pre-Intervention Stage}

1. Setting the scene: The researcher set the scene with students, teachers, and administration. Students' engagement improves when learning objectives are based on student perspectives (Marshall, 2010).

2. Recognizing participants: The researcher recognized participants in terms of number, gender, ages, technology levels and creative writing skills via the pretest

3. Test Analysis: The results analyzed statistically to identify the students' features.

4. Curriculum Deign: The blended learning curriculum was designed in a planned manner based on the analysis results such sd students' interests \& learning styles.

\section{B. During Intervention Stage}

Hofmann (2011) asserts that some influential factors play a role while carrying out any program such as: ensuring participants' ability to use technology, looking at how to teach, not just what to teach.

Selecting Memoir Samples: A number of memoir samples were selected to be read $\mathrm{b}$ students for having fun and explaining the memoir features. Memoir Tools: They included visual graphic novels, picture books, artifacts, photographs, albums, cutouts from magazines and newspapers, images from the Internet, and hand-drawn pictures to create stories.

Writing Drafts: Students got engaged in rewriting exercises, traded early drafts of assignments with peers and revised writing after a conference.

Constructive Learning: Students practise writing as a social activity, constructed knowledge, and wrote after reading selection. 
As a craft: Dealing with writing as a craft and a process rather than a product via students' interaction in workshops.

Creating a community of learners: Cochrane and Bateman, 2011:119) state that communities of practice began to occur as students share knowledge and experiences. Garrison and Vaughan, (2008) promoted a blended Community of Inquiry that combines face-to-face workshops.

\section{Post intervention Stage}

By the end of program, the researcher administered a posttest to explore the program effectiveness on enhancing the students' English creative writing skills. Afterwards, students filled in a satisfaction questionnaire survey to show their attitudes towards the program impact.

\section{The Program Overall Objectives}

$\checkmark$ Providing students with the basic rules of creative writing skills.

$\checkmark$ Enhancing the teachers' awareness towards creative writing

$\checkmark$ Constructing a new motivating atmosphere of learning.

$\checkmark$ Combining the best elements of online teaching and classroom live instruction.

\section{The Program Detailed Objectives:}

a. Content: Writing developed sentences in effective language.

b. Organization: Establishing the topic and the purpose in the introduction Writing body with subtle ideas and supporting details.

c. Style: Using effective language, sensory verbs and similes.

d. Mechanics: Spelling, punctuation and grammar correctly.

The Program Content and Material: The content and material of the program were selected from you tube, slide share, and other related sites. 
The Adopted Blended Model (Table 3.2)

\begin{tabular}{|c|c|c|}
\hline \multicolumn{3}{|c|}{ A Modified Blended Learning Model } \\
\hline Analysis Phase & $\begin{array}{l}\text { - } \text { Analyzing learners' } \\
\text { characteristics. } \\
\text { - } \text { Analyzing blended learning } \\
\text { content } \\
\text { - } \text { Determining instructional aims }\end{array}$ & $\stackrel{60}{=}$ \\
\hline Design Phase & $\begin{array}{l}\text { - Questionnaire surveys and tests } \\
\text { - Blended learning presentation } \\
\text { strategies } \\
\text { - Instructional techniques and } \\
\text { activities }\end{array}$ & 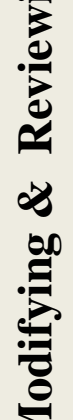 \\
\hline $\begin{array}{c}\text { Production } \\
\text { Phase }\end{array}$ & $\begin{array}{l}\text { - Producing study tools } \\
\text { - Producing required content } \\
\text { factors } \\
\text { - Producing virtual and physical } \\
\text { support. }\end{array}$ & . \\
\hline $\begin{array}{c}\text { Implementation } \\
\text { Phase }\end{array}$ & $\begin{array}{l}\text { - } \text { Pilot experiment - } \text { Pre- } \\
\text { implementation. } \\
\text { - } \text { Blended learning model } \\
\text { implementation. }\end{array}$ & है \\
\hline $\begin{array}{c}\text { Evaluation } \\
\text { Phase }\end{array}$ & $\begin{array}{l}\text { - } \text { Post implementation - } \\
\text { Statistical processing. } \\
\text { - Analyzing and discussing } \\
\text { results. }\end{array}$ & \\
\hline
\end{tabular}


Piloting the Program: A sample unit was selected to be piloted on 10 students for a week; 2 hours each lesson in order to receive feedback about the proposed program. The teaching unit combines a group of lessons designed to teach students the skills and strategies involved in memoir writing and literary books reading.

Setting the Program: The program was conducted at Nile Official School for languages with the $3^{\text {rd }}$ prep graders. It is one of the Official schools for languages.

The Program Duration of time: The program lasted for three months, twelve weeks, two times a week in a two hour sessions, from Sep.to December 2016/2017.

Assessment Techniques: Formative and summative assessment were conducted to evaluate what occurred during the program implementation and the program effectiveness at the end of the program.

Assessment Validity: The initial drafts of tools were introduced to a panel of specialists in English language and methodology from ASU University, experienced supervisors and teachers in Official schools for languages as shown in.

\section{Validity and Reliability:}

1. Using multiple sources of data collection instruments.

2. The internal validity was maintained through the causal relationship the researcher may draw from the evidence and data retrieved from the study.

3. Using many plausible explanations found in the literature review. 
4. Validity could be achieved also by offering the study tools to a number of experts who are specialized in the same field." (Ebeedat et al. 2005: 160).

5. Regarding reliability, the final test of the quality of design is concerned with whether the study can be replicated with similar findings. Reliability means to make data collection can be repeated.

\section{Study Results:}

- Students could use figurative language including metaphors, figures of speech and vivid descriptive memoirs with rich details.

- Students could show how much they are interested in the topic and speak voice in such a way that takes the readers' attention.

- Students' motivation could push up the temperature of writing.

- Students' communication, self-confidence, accountability and independence, besides social and critical thinking were fostered and substantiated.

- Teacher could recognize his students' strengths and weaknesses, work on the weaknesses and consolidate the strengths.

- A rapport between student students and students 'teacher was built. This rapport created mutual trust, comfort and a spirit of openness.

- The students' mechanics of writing such as capitalization, spelling and punctuation promoted and prevented any confusion to happen.

\section{Study Conclusions:}

Blended learning motivates students via the continuous interaction with synchronous and asynchronous activities.

Blended learning offers different sorts of assessments including self, peer and teacher assessment. 
The availability of on-line and off-line resources enables students to revisit the language at the ease and comfort of time.

Blended learning provides great opportunities for low and intermediate achievers to get involved with higher achievers and learn from them.

Blended learning is a good solution to the crowded classes and learning difficulties provided that it had been well planned, designed \& implemented.

\section{Study Recommendations:}

- Enriching the English curriculum in Egypt with different activities.

- Supplying schools with the necessary equipment for employing BL such as enough computer labs, smart boards \& multi-media.

- Activating BL by making teachers facilitators and supporters.

- Preparing and publishing materials to increase teachers' awareness.

- Conducting courses to help teachers enhance their competencies.

- Hoding workshops \& conferences to familiarize teachers with BL.

- Using blended learning to create effective learning environment.

- Enriching curriculum with activities that enhance language practice.

- Considering the individual differences and learning styles.

\section{REFERENCES}

Ausburn, L. J. (2004). Course design elements most valued by adult learners in blended online education environments: An American perspective. Educational Media International, 41(4), 327-337.

Clouder, D. L. (2008). Technology-enhanced learning: conquering barriers to interprofessional education. The Clinical Teacher, 5(4), 198-202. 
Cochrane, T., \& Bateman, R. (2011). Strategies for mlearning integration: Evaluating a case study of staging and scaffolding mlearning integration across a three-year bachelor's degree. Waikato Journal of Education, 16(1), 107-122.

Coen, S. J. (2009). Reading memoirs of childhood. The International Journal of Psychoanalysis, 90(1), 145-156.

Dziuban, C., Moskal, P., \& Hartman, J. (2005). Higher education, blended learning, and the generations: Knowledge is power: No more. Elements of quality online education: Engaging communities. Needham, MA: Sloan Center for Online Education.: Engaging Communities, 85-102.

Ebeedat, Th., Adas A. \& Abel-Haq K. (2005). "Scientific Research, concept, techniques and tools." Amman, Jordan: Dar Alfeker.

Garrison, D. R., \& Vaughan, N. D. (2008). Blended learning in higher education: Framework, principles, and guidelines. John Wiley \& Sons.

Gilbert, R. (2003). Black Dog of Fate, A Memoir, and: Defying Hitler, A Memoir (review). Fourth Genre: Explorations in Nonfiction, 5(2), 158-160.

Graham, C.R. (2004). Blended learning systems: Definition, current trends, and future directions. In The handbook of blended learning: Global perspectives, local designs, ed. C.J.Bonk and C.R. Graham, 3-21. San Francisco: Pfeiffer. Retrieved 123 March 23rd, 2015- Available at:

http://www.academia.edu/563281/Blended_learning_systems_Definition_current_t rends_and_future_directions

Halliday, M., \& Hasan, R. (1985). Language, context, and text: Aspects of language in a social emiotic perspective. Deakin: Deakin University.

Harris, P., Connolly, J., \& Feeney, L. (2009). Blended learning: overview and recommendations for successful implementation. Industrial and Commercial Training, 41(3), 155-163.

Hofmann, J. (2011). Soapbox-Top 10 Challenges of Blended Learning. TrainingSkokie, 12. Retrieved March 23rd, 2016- Available at: http://www.trainingmag.com/article/soapbox-top-10-challengesblended-Learni 
Huang, R. H., Zhou, Y. L., \& Wang, Y. (2006). Blended Learning: Theory into Practice.

Kapka, D., \& Oberman, D. A. (2001). Improving Student Writing Skills through the Modeling of the Writing Process.

Keys, C. W. (2000). Investigating the thinking processes of eighth grade writers during the composition of a scientific laboratory report. Journal of research in science teaching, 37(7), 676-690.

Kirby, D. L., \& Kirby, D. (2007). New directions in teaching memoir: A studio workshop approach.

Langan, J. (2007). Exploring writing: Sentences and paragraphs. McGraw-Hill.

Larson, T. (2007). The memoir and the memoirist.

Marshall, S. (2010). A quality framework for continuous improvement of e-Learning: The e-Learning Maturity Model. International Journal of E-Learning \& Distance Education, 24(1), 143-166.

Mccown, L. J. (2010). Blended courses: the best of online and traditional formats. Clinical Laboratory Science, 23(4), 205.210

McGee, P., \& Reis, A. (2012). Blended Course Design: A Synthesis of Best Practices. Journal of Asynchronous Learning Networks, 16(4), 7-22.

Murdock, M. (2010). Memoir as contemporary myth. Pacifica Graduate Institute.Nonfiction, C. (2003). Creative Nonfiction. Dictionary of Literary Biography Yearbook 2002, 188.

Ramet, A. (2011). Creative writing. Hachette UK.

Sharma, P., \& Barrett, B. (2007). Blended learning: Using technology in and beyond the language classroom. Macmillan.

Slotkin, M., Durie, C., \& Eisenberg, J. (2012). The benefits of short-term study abroad as a blended learning experience. Journal of International Education, 5(2), 163-173.

Smelser, L. M. (2002, March 20-23). Making connections in our classrooms: Online and off. Paper presented at the Annual Meeting of the Conference on College Teaching: a Guide for Language Teachers. NY: Cambridge University Press. 
Stefanovic, D., Miodrag, D., Nikolic, J., Scepanovic, D., Radjo, I., \& Drid, P. (2011). Empirical study of student satisfaction in e-learning system environment. Technics Technologies Education Management, 6(4), 1152-1164.

Stewart, M., Stott, T., \& Nuttall, A. (2011). Student engagement patterns over the duration of level 1 and level 3 geography modules: Influences on student attendance, performance and use of online resources. Journal of Geography in Higher Education, $35(1), 47-65$.

Tang, X. F. (2006). Principles in Teaching Process Writing in a Learner-Centered Classroom. Sino-US English Teaching, 3(2), 52-54. 